\title{
Integrative biomarker assessment of the effects of chemically and mechanically dispersed crude oil in Pacific oysters, Crassostrea gigas
}

Andrea Luna-Acosta ${ }^{\mathrm{a}, \mathrm{b}, \#, *}$, Paco Bustamante ${ }^{\mathrm{a}}$, Hélène Thomas-Guyon ${ }^{\mathrm{a}}$, Beñat Zaldibar ${ }^{\mathrm{b}}$, Urtzi Izagirre $^{\mathrm{b}}$, Ionan Marigómez

a Littoral Environnement et Sociétés (LIENSs), UMR 7266, CNRS-Université de La Rochelle, 2 rue Olympe de Gouges, F-17042 La Rochelle Cedex 01, France

${ }^{\mathrm{b}}$ CBET Res Grp, Res Ctr Experimental Marine Biology \& Biotechnology (PIE) \& Zoology \& Cell Biology Dept. (Science and Technology Fac.) Univ. Basque Country (UPV/EHU), PO Box 644, E48080 Bilbao, Basque Country (Spain)

* Corresponding author: A. Luna-Acosta

Departamento de Ecología y Territorio

Universidad Javeriana

Transv. 4 No. $42-00$

Bogotá, Colombia

Email: aluna1508@yahoo.com

Tel: +5713208320 (ext 4824)

Fax: +5713208320 (ext 4847)

\#Present adress: Departamento de Ecología y Territorio, Universidad Javeriana, Transv. 4 No. 42-00, Bogotá, Colombia. 
Abstract: The impact of dispersed crude oil and dispersant on adult Pacific oysters, Crassostrea gigas, was evaluated through an integrative biomarker approach including (1) biochemical (plasma catecholase- and laccase-type phenoloxidase and superoxide dismutase), (2) histological (digestive cell lysosomal responses, digestive gland histopathology) and (3) physiological (flesh condition index) endpoints in the haemolymph and digestive gland. Adult oysters were exposed to non-contaminated water (control), chemically-dispersed oil (Brut Arabian Light), mechanicallydispersed oil and dispersant (FINASOL®) alone for 2 days, and further depurated in noncontaminated water for 4 weeks. After exposure to chemically and mechanically dispersed oil oysters exhibited induction of plasma laccase-type phenoloxidase and superoxide dismutase activities, enlargement of digestive cell lysosomes, lipofuscin accumulation, reduced neutral lipid content and atrophy of digestive gland diverticula; more markedly on exposure to chemically dispersed oil. From the studied biomarkers, only lysosomal biomarkers were significantly affected after exposure to the dispersant alone. This included lysosomal enlargement, neutral lipid depletion and lipofuscin accumulation in the digestive gland epithelium. A recovery of plasma enzyme activities was observed after 4 weeks of depuration. The integrative biological response index indicated that chemically dispersed oil caused significantly higher stress to $C$. gigas than the mechanically-dispersed one or the dispersant alone; nevertheless, the response seems to be reversible after depuration.

Keywords: dispersant, oil spill, bivalve, invertebrate, biomarker, Integrated biomarker response 


\section{Introduction}

Accidental oil spills constitute a relevant economic and ecological problem of public concern. Economic and ecological consequences of spilled oil can be minimised with chemical dispersants, which are surface active agents or surfactants that enhance the solubilisation of oil slicks in the water column (NRC, National Research Council, 2005; Lee et al., 2015). Third generation compounds replaced earlier generations of oil dispersants by the mid 70s. These mixtures are more efficient than the previous generations and are less toxic. Most of the products marketed today belong to this category. However, lethal and sublethal toxicities of this type of dispersants (e.g. Corexit 9500) and of chemically dispersed oil have been reported in recent studies (Almeda et al., 2014; Goodbody-Gringley et al., 2013). Paradoxically, chemically dispersed oil is cleaned from the environment by degradation and enhanced biodegradation but the process also renders hydrocarbons more bioavailable for marine filter-feeding organisms and results in more severe effects (Baussant et al., 2001; Luna-Acosta et al., 2011); moreover, surfactants themselves can be noxious (Ostroumov, 2003). As a result, the utilitarian value of dispersants as alternatives to mechanical oil removal in the marine environment is still under discussion. Among filter-feeding organisms, the Pacific oyster Crassostrea gigas has proven to be useful for biomonitoring chemical contamination in coasts and estuaries (Beliaeff et al., 1998; O'Connor, 2002). This leading aquaculture product (FAO, Food and Agriculture Organization, 2014) has preferentially been chosen as a sentinel organism for its ability to concentrate pollutants, its immobility, its limited ability to metabolize accumulated contaminants, its relative wide distribution among habitats, its abundance, its persistence, and its ease of collection, all of which makes it a good long-term integrator of the environment (O'Connor, 2002).

To cope with the presence of pollutants in the environment, $C$. gigas may activate stress responses determined as biomarkers. Biomarkers are useful tools for assessing pollution impact on living organisms and for early diagnosis of ecosystem health disturbance (Cajaraville et al., 2000; 
Marigómez et al., 2013a). Among biomarkers, superoxide dismutase (SOD) is an antioxidant enzyme that catalyzes the dismutation of superoxide anion $\left(\mathrm{O}_{2}{ }^{-}\right)$, a highly reactive oxygen species (ROS), into oxygen $\left(\mathrm{O}_{2}\right)$ or hydrogen peroxide $\left(\mathrm{H}_{2} \mathrm{O}_{2}\right)$ (Neumann et al. 2001). The extent to which ROS produce biological damage depends on the effectiveness of antioxidant defences, such as SOD (Neumann et al., 2001). Other enzymes involved in defence mechanisms in bivalves include phenoloxidases (POs). POs are a family of copper proteins and are the rate limiting enzymes in melanisation. POs are also involved in many cellular defence responses in invertebrates, such as self/non-self recognition, phagocytosis and nodule and capsule formation (Asokan et al., 1997). Tyrosinase-type POs catalyse the oxidation of monophenols to quinones, but have not been detected in C. gigas (Luna-Acosta et al., 2010). Catecholase-type POs catalyse the oxidation of diphenols to quinones and have been detected in C. gigas. Laccase type POs catalyse the oxidation of aromatics, including polycyclic aromatic hydrocarbons (PAHs), by an indirect mechanism involving the participation of an oxidative mediator (Dodor et al. 2004), and have been detected in C. gigas (Luna-Acosta et al., 2010). Both SOD and POs in plasma have responded on exposure to a variety of chemical pollutants in bivalves, including petroleum hydrocarbons (Bado-Nilles et al., 2009; Luna-Acosta et al., 2011, 2015; Valavanidis et al., 2006).

Likewise, changes in lysosomal size, contents and membrane stability and atrophy of digestive gland diverticula are considered highly responsive biomarkers of the effects induced by petroleum hydrocarbons and related organochemicals (Lekube et al., 2014; Marigomez et al., 2006; Marigómez and Baybay-Villacorta, 2003). Additionally, histopathological alterations provide complementary and environmentally relevant information about the consequences of environmental insult in mollusc health (Kimet al., 2006). The flesh condition index is one of the best indicators of gross body state for environmental studies; it can also reflect sub-lethal physiological changes from a stressful xenobiotic exposure (Duquesne et al., 2004; Hyötylänen et al., 2002; Widdows et al. 1981). 
Within this context, the present studywas aimed to compare, under controlled laboratory conditions, the effects of chemically and mechanically dispersed crude oil in C. gigas upon the application of an integrated biomarker approach; this included: (a) catecholase- and laccase-type phenoloxidase (PO) and superoxide dismutase (SOD) activities in haemolymph plasma, (b) lysosomal responses in digestive cells, (c) digestive gland histopathology and (d) Flesh Condition Index (FCI) levels. Enzyme responses may occur very rapidly, i.e. within 2 h. For this reason, a time course evaluation of enzyme responses was done at 0, 2, 10, 24 and 48 h. Histological and physiological changes occur more slowly than enzyme responses and these changes were studied at $48 \mathrm{~h}$ of exposure. A total exposure period of $48 \mathrm{~h}$ was selected because it corresponds to four tidal cycles in France. This exposure regime was chosen in order to reflect realistic conditions of coastal pollution in which the dilution process is expected to reduce the dispersed oil concentration. Following the exposure period, oysters were placed in a recovery period of 4 weeks in non-contaminated water to see if sublethal effects could be detected and if initial sub-lethal effects would have long-term consequences.

\section{Materials and methods}

Adult oysters, $C$. gigas (length $=9 \pm 1 \mathrm{~cm}$, purchased at Naissain, France, in May) were acclimatised in the laboratory at $20 \pm 1{ }^{\circ} \mathrm{C}$ for 2 weeks before starting the experiments. The oxygen saturation of water in each tank used for the complete experiment was maintained at around $96 \%$ by air compressor via an air diffuser. During acclimatisation (as well as during depuration following exposure treatments but not during exposure to chemicals) oysters were fed daily with Heteroskeletonema sp. $(5 \times 104$ cell $\mathrm{ml}-1)$, purchased from a hatchery (SATMAR, Normandie, France).

Brut Arabian Light (BAL) crude oil was selected because of its worldwide use, its physical and chemical properties and information available. It has the following physico-chemical 
characteristics: density $\left(20^{\circ} \mathrm{C}\right)=0.860$; viscosity $\left(15^{\circ} \mathrm{C}\right)=60 \mathrm{mPa} \cdot \mathrm{s} ; 12 \%$ polar compounds, $34 \%$ aromatic hydrocarbons and 54\% saturated hydrocarbons. To simulate natural weathering after oil spills, BAL crude oil was topped at $110^{\circ} \mathrm{C}$ (BAL 110) to eliminate its most volatile compounds. The chemical dispersant (D) used in this study was selected following an evaluation carried out by the Centre of Documentation, Research and Experimentation on Accidental Water Pollution (http://www.cedre.fr/en/response/dispersant.php; CEDRE, France); thus, it was effective for use in the marine environment (norm NF.T.90-345), non-toxic (norm NF.T.90-349) at the concentration recommended by the manufacturer (Total Fluides Sas, Puteaux, France) and biodegradable (norm NF.T.90-346). The dispersant corresponds to a third generation chemical dispersant of the series type FINASOL®. According to manufacturer's instructions, a 5\% v/v dilution was used for the present experimental treatments. The chemical formulation of the dispersant was not available for reasons of confidentiality.

\subsection{Experimental design}

BAL 110 polluted seawater consisted of 20 g BAL 110 added to 3001 seawater (i.e. 67 ppm) in order to obtain a realistic concentration of dispersed oil in the range of those reported in situ following an oil spill (e.g., Braer oil spill; Lunel, 1995). The following dispersion treatments were carried out: control (C) with non-contaminated water, chemical dispersion (CD)with $20 \mathrm{~g}$ of BAL 110 and $5 \%$ of dispersant (i.e. $1.2 \mathrm{~g}$ or $4 \mathrm{ppm}$ ), mechanical dispersion (MD) with $20 \mathrm{~g}$ of BAL 110 and dispersant (D) with $1.2 \mathrm{~g}$ of dispersant. Experiments were carried out at $20{ }^{\circ} \mathrm{C}$, summer seawater temperature at which oysters are known to respond to pollutant insult (Gagnaire et al., 2006). A funnel (at the surface of each tank) was connected to a submersed Johnson L450 water pump (at the bottom of the tank), in order to maintain the mixture of oil and dispersant as a homogenous solution (Milinkovitch et al., 2011); this device was applied to all tanks, including the control ones (Fig. 1). The same volumes of BAL110 and dispersant, the same dispersant and 
the same homogenization system have been used in previous studies (e.g. Milinkovitch et al., 2011).

Initially, chemicals were added to the seawater. Preliminary tests confirmed that total petroleum hydrocarbon concentrations in the water column were depth-independent, suggesting that small petroleum droplets were homogeneously dispersed in the water column (data not shown). When chemicals were completely homogenized in the tanks, i.e. $12 \mathrm{~h}$ later, the exposure period began $\left(\mathrm{t}_{0}\right)$. Ten oysters of the initial stock were used at $\mathrm{t} 0$ for biochemical analyses and remaining oysters $\left(\mathrm{N}=70\right.$; per tank) were introduced into the tanks for $48 \mathrm{~h}\left(\mathrm{t}_{48}\right)$. The seawater was not changed during the acclimation or exposure period. The oysters were exposed to these different conditions for a period of $48 \mathrm{~h}$ corresponding to four tidal cycles in France. This exposure regime was chosen in order to reflect realistic conditions of coastal pollution in which the dilution process is expected to reduce the dispersed oil concentration. At 2, 10, 24 and $48 \mathrm{~h}$ of exposure, 10 oysters were retrieved per treatment for biochemical analyses (Fig. 1). Histological and physiological analyses were also performed in oysters retrieved at $\mathrm{t}_{48}$. Further on, remaining oysters were depurated in a new tanks with non-contaminated seawater for 4 weeks, and at the end of that period, 10 oysters per treatment were retrieved for depuration analyses. The experiment was replicated three times (i.e. exposure period with the 4 treatments for $48 \mathrm{~h}$ and depuration period for 4 weeks) and were carried out in parallel (Fig. 1).

\subsection{Determination of TPHs in seawater}

The concentration of total polycyclic hydrocarbons (TPH; dissolved hydrocarbon plus oil droplets) in seawater $([\mathrm{TPH}] \mathrm{sw})$ was measured for the 3 experimental replicates. Three analytical replicates were measured at the beginning (t0), and at the end $(48 \mathrm{~h})$ of the exposure period for each experimental replicate. The mean of the 9 values $(3$ analytical replicates $\times 3$ experimental replicates) were calculated for each experimental time. Each seawater sample was collected using a glass pipette connected to a pipette filler (VWR), and stored in a $60 \mathrm{ml}$ tinted glass bottle (VWR). 
The seawater sample extraction was achieved with $10 \mathrm{ml}$ pestipur-quality dichloromethane (Carlo Erba Reactifs, SDS, France) to separate organic and aqueous phases. Then, water was extracted twice more with the same volume of dichloromethane $(2 \times 10 \mathrm{ml})$. The combined organic layers were dried using anhydrous sulphate and analysed using a UV spectrophotometer (SAFAS Xenius $\mathrm{XM})$ at $390 \mathrm{~nm}$. The detection limit of this method depends on the precision of the spectrophotometer, and results are not reliable for $[\mathrm{TPH}] \mathrm{sw}$ values under $1 \mathrm{mg} \cdot \mathrm{l}^{-1}$. The results were expressed in milligrams per litre, and were compared against BAL 110 standards $\left(5-100 \mathrm{mg} \cdot \mathrm{1}^{-1}\right)$ (Fusey and Oudot, 1976).

\subsection{Determination of enzyme activities in plasma}

Haemolymph samples were collected after 0,2, 10, 24 and 48 h exposure and 4 wk. depuration. Oysters were opened by excising the adductor muscle and $0.5-1 \mathrm{ml}$ haemolymph were withdrawn directly from the pericardial cavity with a 1-ml syringe equipped with a needle $(0.9 \times 25 \mathrm{~mm})$. After hemolymph extraction, oysters were not reintroduced in experimental tanks and the volume of experimental seawater in tanks was maintained. The haemolymph retrieved from 10 oysters was pooled, following previous studies (Luna-Acosta et al., 2011). In addition, no significant differences have been observed for defence responses in C. gigas (including PO) following exposure to pollutants, between individual or pooled samples (Bado-Nilles et al., 2008). Haemolymph samples were centrifuged $\left(260 \mathrm{~g}, 10 \mathrm{~min}, 4^{\circ} \mathrm{C}\right)$ to separate cellular fraction (i.e. haemocytes) and plasma (Luna-Acosta et al., 2010). The plasma was selected for the biochemical determination of SOD and PO activities.

SOD activity was determined as previously described (Luna-Acosta et al., 2011) by applying an indirect spectrophotometric method (kit Ransod SD 125, Randox, France) based on competition of SOD with iodonitrotetrazoliumn (INT) for dismutation of superoxide anion (Therond et al., 1996). One SOD unit is defined as the amount of enzyme that promotes a $50 \%$ decrease in INT reduction rate (Therond et al., 1996). Catecholase- and laccase-type PO activities were determined 
as previously described (Luna-Acosta et al., 2010). For catecholase-type activity, the increase of absorbance at $490 \mathrm{~nm}$ was monitored for $4 \mathrm{~h}$ using dopamine $100 \mathrm{mM}$ as substrate (SigmaAldrich). For laccase type activity, the increase of absorbance at $420 \mathrm{~nm}$ was monitored for $2 \mathrm{~h}$ using p-phenylendiamine $50 \mathrm{mM}$ as substrate (Sigma-Aldrich). For both assays, nonenzymatic oxidation by the substrate was monitored in wells without oyster sample and subtracted from oxidation of the substrate with oyster sample. One unit of catecholase- and laccase type PO activities corresponds to the amount of enzyme that catalyzes the production of $1 \mu \mathrm{mol}$ product per $\min \left(\varepsilon=3.3 \mathrm{M}^{-1} \mathrm{~cm}^{-1}\right.$ and $43.16 \mathrm{M}^{-1} \mathrm{~cm}^{-1}$, respectively; Luna-Acosta et al., 2010). All activities were measured in triplicate for each sample and expressed in relation to protein concentration measured according to the Lowry method with slight modifications, by using bicinchoninic acid and copper sulphate 4\% (Smith et al., 1985). Serum albumin was used as protein standard (SigmaAldrich).

\subsection{Histological processing}

After $48 \mathrm{~h}$ exposure, oysters (30 per experimental group $=10$ per treatment $\times 3$ replicates $)$ were retrieved and their digestive gland and mantle were dissected out. The digestive gland was halved. One half and the mantle tissue were fixed in Davidson's fixative for $24 \mathrm{~h}$ and embedded in paraffin. Paraffin sections $(5 \mu \mathrm{m}$ thick) were obtained using a Leitz 1512 rotary microtome (Ernest LeitzWetzlar GmbH, Austria) and stained with haematoxylin-eosin (H/E). The second half of digestive gland was frozen in liquid nitrogen and stored at $-80{ }^{\circ} \mathrm{C}$ until cryosectioning. Later, cryotome sections $(8 \mu \mathrm{m})$ were obtained in a Leica CM3000 cryotome (Ernest Leitz Wetzlar $\mathrm{GmbH}$, Austria) with a cabinet temperature of $-24{ }^{\circ} \mathrm{C}$. Sections were collected onto warm glass slides and stored at $-40{ }^{\circ} \mathrm{C}$ until required for staining.

\subsection{Quantitative microscopy of digestive cell lysosomes}


Cryotome sections (1 per oyster; 10 oysters per experimental group) were stained for the histochemical demonstration of $\beta$-glucuronidase activity, neutral lipids and lipofuscins.

The histochemical demonstration of $\beta$-glucuronidase activity (incubation for $20 \mathrm{~min}$ ) was used in order to visualise digestive cell lysosomes (Izagirre and Marigómez, 2009). Aided by an image analysis system attached to a light microscope (100x objective lens) 5 measurements were made per section and the following stereological parameters were calculated (Lowe et al., 1981): lysosomal volume density $\left(\mathrm{V}_{\mathrm{V}_{\mathrm{DCL}}}=\mathrm{V}_{\mathrm{L}} / \mathrm{V}_{\mathrm{C}}\right)$, surface density $\left(\mathrm{Sv}_{\mathrm{DCL}}=\mathrm{S}_{\mathrm{L}} / \mathrm{V}_{\mathrm{C}}\right)$, surface-to-volume ratio (inverse to size) $\left(\mathrm{S} / \mathrm{V}_{\mathrm{DCL}}=\mathrm{S}_{\mathrm{L}} / \mathrm{V}_{\mathrm{L}}\right)$ and numerical density $\left(\mathrm{Nv}_{\mathrm{DCL}}=\mathrm{N}_{\mathrm{L}} / \mathrm{V}_{\mathrm{C}}\right)$; where $\mathrm{V}=$ volume, $\mathrm{S}=$ surface, $\mathrm{N}=$ number, $\mathrm{L}=$ lysosomes, and $\mathrm{C}$ =digestive gland cytoplasm. A correction factor for particles with an average diameter smaller than the section thickness was applied.

Neutral lipids were detected by using Lillie and Ashburn's Oil Red O (ORO) staining method (Culling, 1974). Counts were made in 5 fields selected within a given section using a drawingtube attached to a Nikon Optiphot light microscope (40× objective; $\sim 400 \times$ final magnification). A Weibel graticule (multipurpose test system M-168; Weibel, 1979) was used, and hits on ORO vesicles and on the remaining digestive epithelium were recorded enabling the calculation of the volume density of intracellular neutral lipids in digestive cells $\left(\mathrm{V}_{\mathrm{NL}}\right)$ according to Delesse's principle (Weibel, 1979): $\mathrm{V}_{\mathrm{V}_{\mathrm{NL}}}=\mathrm{V}_{\mathrm{NL}} / \mathrm{V}_{\mathrm{C}}$, where $\mathrm{V}_{\mathrm{NL}}$ is the volume of neutral lipids and $\mathrm{V}_{\mathrm{C}}$ the volume of digestive cells (Marigómez and Baybay-Villacorta, 2003).

The histochemical demonstration of lipofuscins was done using the Schmorl's method (Zorita et al., 2006). Counts were made in 5 fields selected within a given section using a drawing-tube attached to a Nikon Optiphot light microscope (40× objective; $~ 400 \times$ final magnification). A M168 Weibel graticule (Weibel, 1979) was used, and hits on lipofuscins and on the remaining digestive epithelium were recorded enabling the calculation of the relative section area of lipofuscins in relation to the section area of digestive cells: $A_{a_{L F}}=A_{L F} / A_{C}$ where $A_{L F}$ is the total section area of lipofuscins and $A_{C}$ the total section area of digestive cells. 


\subsection{Tissue-level biomarkers and histopathology}

Prevalence of parasites, haemocyte infiltration and general condition were systematically examined at the light microscope in H/E stained paraffin sections of digestive gland and scored (Kim et al., 2006). Structural changes in digestive gland epithelium were determined by means of quantitative microscopy on H/E stained paraffin sections. Mean epithelium thickness (MET), mean luminal radius (MLR) and mean diverticular radius (MDR) were determined by stereology (Garmendia et al., 2011b; Vega et al., 1989). A M-168 Weibel multipurpose test system (Weibel, 1979) was superimposed to microscopic images (20× objective; $200 \times$ final magnification) with the aid of a drawing tube attached to the microscope and hits on digestive gland epithelium (d), diverticular lumen (l) and interstitial connective tissue (c) were recorded. The following formulae were applied: MET $=2 \mathrm{~d} \sqrt{ } \pi /(\sqrt{d}+\sqrt{ } 1) ;$ MLR $=\sqrt{ }(1 / \pi)$; and MDR $=\sqrt{ }((d+1) / \pi) ;$ MLR/MET and MET/MDR ratios were calculated as well (Vega et al., 1989). These parameters are indicative of the atrophy in the digestive epithelium and alterations in the digestive diverticula, respectively. Only measurements were made at $48 \mathrm{~h}$ since the samples for recovery time were compromised for procedural mistakes; same for histochemistry.

\subsection{Condition index}

Flesh condition index (FCI) was calculated in 30 oysters $(10$ oysters $\times 3$ experimental replicates $)$ per treatment, after $2 \mathrm{~d}$ exposure and $4 \mathrm{wk}$. depuration, and expressed in $\mathrm{mg}$ flesh dry weight $\cdot \mathrm{g}^{-1}$ shell dry weight (Lobel and Wright, 1982).

\subsection{Integrative biological response index}

The Integrative Biological Response (IBR) index was developed in order to integrate biochemical, genotoxicity and histochemical biomarkers (Beliaeff and Burgeot, 2002). In the present study, SOD, AaLF, Vv, MLR/MET and FCI were used to calculate the IBR index after $48 \mathrm{~h}$ exposure for each experimental replicate. The five biomarkers were selected, based on the following criteria: 
(1) At least one for each level of biological organization studied (i.e. biochemical, histological and physiological); and (2) if similar results were observed at the same level of biological organization (i.e. significant differences in treatments in comparison to Control), only one of the biomarkers was selected for the IBR, to avoid redundance. Biomarkers were orderly represented in the five axes of start plots, from the less (SOD) to the most complex (FCI) biological level (Marigómez et al., 2013a). The calculation method is based on relative differences between the biomarkers in each given data set. Thus, the IBR/n index is computed by summing-up triangular star plot areas (a simple multivariate graphic method) for each two neighboring biomarkers in a given data set (Beliaeff and Burgeot, 2002; Broeg and Lehtonen, 2006).

\subsection{Statistical analyses}

All values are reported as mean \pm standard deviation (SD). Statistical analysis was carried out with STATISTICA 7.0. Values were tested for normality (Shapiro test) and homogeneity of variances (Bartlett's test). In some cases ([TPH]sw, enzyme activities, VvdCL and NvDCL), logarithmic transformations $(\log 10)$ were used to meet the underlying assumptions of normality and homogeneity of variances. For normal values, the following tests were carried out (Zar, 2010): one-way nested ANOVA was used to analyse [TPH]sw results (analytical replicate nested into treatments); two-way nested MANOVA to analyse enzyme activity, with treatment $(\mathrm{C}, \mathrm{CD}, \mathrm{MD}$ and D) and period (exposure and depuration period) as fixed factors, and analytical replicate as a random factor (analytical replicate was nested within each combination of treatment and period); one-way MANOVA to analyse lysosomal biomarkers, VvL, AaLF and MLR/MET; two-way MANOVA to analyse flesh condition index results, with treatment and period as fixed factors; and one-way ANOVA to analyse IBR results. When the null hypothesis (H0: no difference between treatments or within treatment at different time intervals) was rejected, significant differences were tested using Tukey's HSD test. Chi-square statistics were used to test sex ratios (Zar, 2010). Statistical significance was determined at $\mathrm{p}<0.05$. 


\section{Results}

There were significant differences in $[\mathrm{TPH}] \mathrm{sw}$ among experimental groups, especially at t0, with the highest concentration in $\mathrm{CD}$, followed by $\mathrm{MD}$ and the lowest in $\mathrm{C}$ and $\mathrm{D}$ (Fig. 2). Further on, $[\mathrm{TPH}] \mathrm{sw}$ decayed along the experimental time and reached identical values in CD and MD groups after $10 \mathrm{~h}$ exposure, which were only slightly higher than in C and D groups (Fig. 2).

Mortality throughout the experimental period ( $48 \mathrm{~h}$ exposure and $4 \mathrm{wk}$. depuration) was b10\%, which makes valid this test (Rand \& Petrocelli, 1985). This percentage was constant across treatments. No significant effect was recorded on catecholase-type PO activity (data not shown). No significant effect was observed at different periods (including t0) for laccase-type PO and SOD in the $\mathrm{C}$ treatment. However, significant effects were observed between treatments on laccase-type PO (Fig. 3a) and SOD (Fig. 3b) activities, from $2 \mathrm{~h}$ to 4 wk. In CD and MD treated oysters, laccasetype PO activity was enhanced after $10 \mathrm{~h}$ exposure (Fig. 3a),whilst in D treated ones only a less marked and transient (between hours 2 and 10) enhancement was envisaged (Fig. 3a). SOD activity raised promptly (within $2 \mathrm{~h}$ ) in $\mathrm{CD}$ treated oysters (after $2 \mathrm{~h}$ exposure), but not at all in response to MD or D treatment (Fig. 3b). After 4 wk. depuration, all enzyme activities returned to control levels, but it cannot be disregarded that control levels could have been reached much sooner (Fig. $3 \mathrm{a}$ and $\mathrm{b})$. Time-course studies are needed in the future in order to elucidate how quick is recovery, which is just as important as documenting adverse impacts, commonly overlooked in many studies.

No significant presence of parasites was observed in H/E stained paraffin sections of digestive gland. The gonad was mature in all the oysters examined and no clear difference was found among experimental groups. In addition, digestive cell lysosomes were tiny and their section profile area could not be precisely determined, therefore, SvDCL results were not consistent and were not included for discussion. Accordingly, $\mathrm{S} / \mathrm{V}_{\mathrm{DCL}}$ values, which were not dissimilar between treatments, resulted very small $\left(\mathrm{S} / \mathrm{V}_{\mathrm{DCL}}=6.858 \pm 0.792 ; \mathrm{N}=120\right)$. Nevertheless, the digestive cells 
of $\mathrm{CD}, \mathrm{MD}$ and $\mathrm{D}$ treated oysters exhibited high VvDCL and high NvDCL in comparison with control oysters (Fig. 4a and b). Likewise, AaLF was higher in treated oysters than in controls ones, especially in CD treated oysters (Fig. 4c). In contrast, $V_{v_{N L}}$ was markedly reduced in treated oysters ( 60,50 and $40 \%$ lower in CD, MD and D treatments) in comparison with controls (Fig. 4d). Histopathological alterations including luminal swelling, epithelial thinning, a certain degree of digestive cell vacuolisation and haemocyte infiltration were observed in the digestive gland of treated oysters (data not shown), especially after CD treatment and to a lesser extent after MD and $\mathrm{D}$ treatments. This is clearly reflected in the higher MLR/MET values (Fig. 4e), and lower MET/MDR values (data not shown since MET/MDR values are complementary to MLR/MET values), indicating alterations both in the digestive epithelium and diverticula structure in treated oysters compared to control ones (Fig. 5).

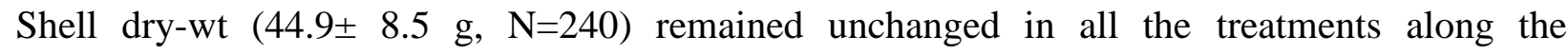
experimental period. Likewise, FCI was not statistically different between treatments $(\mathrm{C}, \mathrm{CD}, \mathrm{MD}$ and D) after $48 \mathrm{~h}$ exposure (ranging between $26 \pm 2$ and $27 \pm 2 \mathrm{mg}$ flesh dry weight $\cdot \mathrm{g}^{-1}$ shell dry weight); however, significant differences were observed after 4 wk. depuration, with higher FCI values in $\mathrm{CD}\left(40 \pm 2 \mathrm{mg}\right.$ flesh dry weight $\cdot \mathrm{g}^{-1}$ shell dry weight $)$ and MD (36 $\pm 2 \mathrm{mg}$ flesh dry weight $\cdot \mathrm{g}^{-1}$ shell dry weight $)$ than in $\mathrm{D}\left(27 \pm 2 \mathrm{mg}\right.$ flesh dry weight $\cdot \mathrm{g}^{-1}$ shell dry weight $)$ and $\mathrm{C}(31$ $\pm 2 \mathrm{mg}$ flesh dry weight $\cdot \mathrm{g}^{-1}$ shell dry weight) treated oysters.

Overall, the IBR index was significantly higher in $\mathrm{CD}, \mathrm{MD}$ and $\mathrm{D}$ treated oysters in comparison to $\mathrm{C}$ oysters and statistically higher in $\mathrm{CD}$ treated oysters in comparison to MD and D treated oysters (Fig. 4f).

\section{Discussion}

TPH concentration in seawater in CD and MD treatments was within the range of those reported after oil spills (e.g., $[\mathrm{TPH}]_{\mathrm{sw}}=1-100 \mathrm{mg} \cdot \mathrm{l}^{-1}$ after the Braer oil spill, Lunel, 1995; $202 \mathrm{mg} \cdot \mathrm{l}^{-1}$ after 
the BP/Deepwater Horizon oil spill, Sammarco et al., 2013) and was higher in CD than in MD seawater at t0, although identical values were reached after $10 \mathrm{~h}$. Chemical dispersion promotes (1) partitioning of hydrocarbons from oil to water (Greer et al., 2012; Wu et al., 2012) and (2) formation of small crude oil droplets in the prey size spectra of suspension feeders (e.g. Almeda et al., 2014). Thus, both the PAH concentration and the proportion of high molecular weight PAHs (highly toxic) in seawater increase as a result of chemical dispersion, as well as their bioavailability (Lee et al., 2015; NRC, National Research Council, 2005). As a result, in comparison with the MD treatment, toxic hydrocarbons would be retained in seawater at the short time after CD treatment; this would render toxic PAHs more bioavailable for oysters (Baussant et al., 2001; Luna-Acosta et al., 2011). In agreement, after $48 \mathrm{~h}$ under the present experimental conditions, CD and MD treated juvenile Pacific oysters, C. gigas, exhibited higher PAH tissue concentrations $(\times 3)$ after CD than after MD treatment (Luna-Acosta et al., 2011). Comparable results were also obtained in juvenile grey mullets, Liza aurata (Milinkovitch et al., 2011). Therefore, a higher sublethal toxicity might be expected after CD than after MD treatment, due to a higher bioavailability of PAHs from BAL 110, in the presence of the chemical dispersant (CD treatment), as below discussed.

Bivalves may activate biomarker responses, such as SOD and POs, to cope with the presence of pollutants in the environment. These biomarkers have shown to respond on exposure to petroleum hydrocarbons in bivalves (Bado-Nilles et al., 2009; Luna-Acosta et al., 2011, 2015; Verlecar et al., 2007). In the present study, no effect was observed on catecholase-type activity. However, laccase enzyme activity in plasma was enhanced in CD treated oysters, especially for the first $24 \mathrm{~h}$ of exposure, and to a lesser extent and more delayed in MD treated oysters. Accordingly, laccase gene expression was up-regulated in adult $C$. gigas haemocytes after $7 \mathrm{~d}$ exposure to the water soluble fraction of a light crude oil (Bado-Nilles et al., 2009). Laccase-type POs catalyse the oxidation of aromatics, including polycyclic aromatic hydrocarbons (PAHs; Dodor et al. 2004), while catecholase-type POs catalyse the oxidation of diphenols to quinones, which could explain differences observed in the response of both enzymes in this study. Because of laccase affinity to 
aromatic compounds (Dodor et al., 2004), its activity induction may provide protection against PAHs. The more marked activation observed in laccase in CD compared to MD is seemingly related to the higher TPH concentration measured in seawater at the beginning of the experiment. Interestingly, the attenuation in the differences in laccase-type PO activity between CD and MD treated oysters runs in parallel with the attenuation in the differences in TPH concentration in seawater along the experimental time. Nevertheless, this protective mechanism seems to be effective in adult oysters but not necessarily in other life stages, as laccase activity was inhibited in juvenile oysters exposed to hydrocarbons (Luna-Acosta et al., 2011). This is not surprising because the resistance against pollutants and the associated protective mechanisms are known to vary largely between life stages in bivalves (Harrison et al., 1984). In parallel, SOD activity was promptly enhanced in CD treated oysters but not in MD or D treated oysters. Since SOD is an antioxidant enzyme known to be induced in PAH exposed bivalves (e.g. Orbea et al., 2002), the high SOD activity recorded in CD oysters would be in agreement with a high bioavailability of PAHs after CD treatment. Besides, enhancement of laccase activity can promote additional ROS production and thus contribute to enhance SOD activity (Winston, 1991). Therefore, CD treatment provoked the highest antioxidant response, which was early induced. Finally, it is worth noting that both laccase-type PO and SOD enzyme activities returned to control levels after 4 weeks in clean seawater, which indicates that these biological responses are fully reversible upon removal of the contaminant. Summarizing, chemical dispersion of oil slicks may have more marked effects on certain target enzymes of adult $C$. gigas than mechanical dispersion or the dispersant alone, as previously suggested for juvenile oysters (Luna-Acosta et al., 2011).

A return to control levels is in agreement with previous studies carried out in other marine species exposed to oil (Hannam et al., 2009; Webby and Ling, 2016; Mauduit et al., 2016). Hannam et al. (2009) assessed the impact of dispersed oil exposure on immune endpoints in the Arctic Scallop Chlamys islandica, using a combination of cellular and humoral biological responses. Oil used in that study was the water-accomodated fraction (WAF) of North Sea crude oil. Laboratory 
exposures of $C$. islandica to sub-lethal dispersed oil concentrations were conducted over 15 days, followed by a 7-day recovery period in clean, filtered seawater. Whilst results indicated alteration in the immune endpoints measured, this appeared to be reversible upon removal of the contaminant stress. Exposure of the European seabass (Dicentrarchus labrax) to weathered Arabian crude oil and dispersant (4\% of Corexit EC9500A) mixture for $48 \mathrm{~h}$ was associated with temporarily impaired health (Mauduit et al., 2016), while exposure to dispersant and to oil alone did not affect fish health. Fish health recovery was confirmed by the absence of long-term effects (almost 1 year post-exposure). Webby and Ling (2016) evaluated sublethal effects of the water soluble fractions of physically and chemically dispersed heavy fuel oil (HFO) and the water soluble fraction of cryolite on the haematology of subadult or adult snapper (Chrysophrys auratus), spotted wrasse (Notolabrus celidotus) and red rock lobster (Jasus edwardsii). In most cases, physiological indices returned to control levels by the end of the $96 \mathrm{~h}$ exposure period after a brief disruption and there were no further signs of haematological disruption during a further 10 days of depuration.

Lysosomal enlargement in molluscan digestive cells constitutes a general response to pollutants, which usually is accompanied by reduction in lysosome numbers (e.g. Izagirre and Marigómez, 2009). In general, lysosomes were very small (high S/VDCL), which is in agreement with previous studies performed in oysters (Díez, 1996); this only allowed a limited interpretation of the obtained data. However, lysosomal enlargement (high $\mathrm{Vv}_{\mathrm{DCL}}$ and $\mathrm{Nv}_{\mathrm{DCL}}$ ) was elicited in digestive cells, in all the treated oysters but especially in CD treated ones. These results suggest that not only oil, both chemically and mechanically dispersed, but also the employed dispersant exert sublethal toxic effects on oysters, as previously reported in other marine species (e.g. Almeda et al., 2014; Goodbody-Gringley et al., 2013; Mu et al., 2014; Ostroumov, 2003). Likewise, VvNL was markedly reduced in all the treated oysters in comparison with controls, and once again more markedly in CD treated oysters.

The total lipid content in bivalves may decline with nutritional stress and increase in response to another stress sources or at certain moments of the reproductive cycle, e.g. with gamete ripeness 
(Shaw et al., 2011). In this case, the use of reserves to satisfy the extra demand of energy required to face pollutant insult might have led to lipid consumption resulting in lower $\mathrm{Vv}_{\mathrm{NL}}$ in treated than in control oysters. In agreement, reduced levels of intracellular lipids have been related to poor nutritional status or to certain moments of the gametogenic cycle (Marigómez et al., 2013b; Shaw et al., 2011). Lipofuscins are pigments considered as the terminal products of the lipid peroxidation that accumulate in lysosomes as a result of environmental insult as well as with age (Moore et al., 2006). Presently, lipofuscins were accumulated in treated oysters, most markedly in CD treated oysters. These results are in agreement with previous studies that demonstrated lipofuscin accumulation within the digestive cells of mussels exposed to PAHs, organochlorides and metals (Krishnakumar et al., 1997; Marigómez et al., 2013a; Viarengo et al., 1990).

On the other hand, subtle histopathological effects were observed in the digestive gland of treated oysters including luminal swelling, epithelial thinning, certain degree of digestive cell vacuolisation and haemocyte infiltrations, especially in CD and MD treated oysters and, to a lesser extent after D treatment. Similar effects have been reported in stressed bivalves (Garmendia et al., 2011; Marigómez et al., 2013a). Accordingly, MLR/MET and MET/MDR were significantly different in CD in comparison with the three other experimental groups. MLR/MET was also the most sensitive tissue-level biomarker in mussels after the Prestige oil spill, MLR/MET reduction being marked from Galicia to the Basque Coast for 3 years, from2003 to 2006 (Garmendia et al., 2011b). Overall, it seems that the effects at the histological level are not severe, which can be due to the short duration of the exposure. Indeed, histopathological alterations in sentinel molluscs are considered indicative of mid- (days to weeks) to long-term(weeks to months) effects, although the very first symptoms are evident within a few days (1-3), as in the present study (Garmendia et al., 2011). It should also be noted that in the experimental design histological and histochemical measurements were included to determine the effects at higher biological organization levels. Results confirmed the effects at tissue level exerted by chemically dispersed oil even at very short exposure time. 
Higher FCI was recorded after 4 wk. depuration in CD and MD treated oysters in comparison with control oysters. FCI is known to decrease or remain unchanged in oil exposed bivalves (Brooks et al., 2011; Van Scoy et al., 2010). Other authors (e.g. Duquesne et al., 2004), have observed increase in FCI in bivalves exposed to pollutants, such as heavy metals, and have attributed it to hormesis, which is a cumulative consequence of an adaptive response common to biological systems (Stebbing, 1998). However, oil exposure may produce spawning arrest and lead to increase FCI (Baussant et al., 2011; Marigómez et al., 2013b), which is not unlikely to have happened in $\mathrm{CD}$ and to a lesser extent MD treatments.

Overall, IBR/n index was higher in exposed oysters than in the other treatments. In mussels and clams, IBR index provides indication of environmental stress caused by pollution, even in the presence of mixtures of chemicals present at concentrations below or nearby their detection limits (Beliaeff and Burgeot, 2002; Broeg and Lehtonen, 2006; Marigómez et al., 2013a). It seems that chemical dispersion of oil slicks may have more noxious effects in the Pacific oyster, C. gigas than mechanical dispersion. Recent studies have also revealed that chemical dispersants enhance bioaccumulation and/or effects of oil in marine planktonic copepods (Almeda et al., 2014), fish (Mu et al., 2014) and roundworm (Bolt, 2014).

Other authors have also found long-term effects following chemical or mechanical dispersion (e.g. Vignier et al., 2015; Frantzen et al., 2016; for review, see Beyer et al., 2016). Vignier et al. (2015) found that the exposure of oyster gametes and embryos to oil preparations (crude oil obtained from the Deepwater Horizon oil spill) and dispersant (Corexit 9500A) impaired fertilization success, the normal development of embryos to the larval stage, and the growth of the resulting larvae. It also induced larval death, with dispersed oil and dispersant alone producing the highest impact. These results suggest that oil spills and employing dispersants to disperse oil at the time of the oyster spawning season could affect oyster recruitment and, ultimately, oyster resources in affected regions. Frantzen et al. 2016 did not found marked differences in sub-lethal short- or long-term responses between corresponding chemically and mechanically dispersed oil treatments in 
Icelandic scallops $C$. islandica, using naphthenic crude oil (Troll) from the North Sea and the Dasic NS dispersant. However, the authors observed a concentration dependent increase in cumulative post-exposure mortality, suggesting long-term effects of chemically and mechanically dispersed oil in these bivalves. Moreover, according to the review of Beyer et al. (2016), the use of oil dispersing agents in offshore waters during the Deepwater Horizon oil spill enhanced the bacterial degradation of oil, but also increased the bioavailability (and hence ecotoxicity impact) of the oil in certain offshore habitats.

In conclusion, the present results suggest that chemically-dispersed oil exerts more remarkable sublethal effects in oysters in comparison to mechanically-dispersed oil and that dispersant provokes some sublethal toxicity, at least transiently; as reported for other biological effects endpoints and in other marine animals (Almeda et al., 2014; Baussant et al., 2011; GoodbodyGringley et al., 2013; Ostroumov, 2003) and in oyster early life stages (Luna-Acosta et al., 2011). These results suggest also that if the chemical dispersant of the series type FINASOL® is used to respond to an oil spill, long-term effects are not expected in oysters. However, based on results of FCI after 4 wk. of depuration in the present study, and on results on mortality, early development and fertilization in other studies (Vignier et al., 2015; Frantzen et al., 2016; for review, see Beyer et al., 2016), the effects of chemically and mechanically dispersed oil on growth, survival and reproductive development cannot be fully discharged. Therefore, further researches in C. gigas and in other bivalve species are needed to strengthen the knowledge base required to establish recommendations and potential long-term effects of using chemical dispersants in coasts and estuaries.

Acknowledgements. A. Luna-Acosta was recipient of a Post-Doctoral grant (Conseil Général de la Charente-Maritime) and for financial support by Basque Government (Consolidated Res Grp GIC10/168 and IT810-13) and Basque Country Univ. (UFI 11/37) to develop this research. Thanks to the Programme Ecotechnologies et Développement Durable (PRECODD) of the Agence 
Nationale de la Recherche (ANR) for financial support for the project 'DISCOBIOL' ("Dispersants et technique de lutte en milieux côtiers : effets biologiques et apports à la réglementation"), ANR-07-ECOT-004-03. Authors are deeply indebted to Total Fluides Sas for providing chemicals, to J. Laheux and M. Pelmoine from LIENSs (La Rochelle Univ.) and to S. Labrut and J. Abadie from ONIRIS (Ecole Nationale Vétérinaire, Agroalimentaire et de l'Alimentation Nantes-Atlantique) for their technical assistance. We thank Chris Applebee for English revision.

\section{References}

Almeda, R., Baca, S., Hyatt, C., Buskey, E.J., 2014. Ingestion and sublethal effects of physically and chemically dispersed crude oil on marine planktonic copepods. Ecotoxicology 23:988-1003. http://dx.doi.org/10.1007/s10646$\underline{014-1242-6 .}$

Asokan, R., Arumugam, M., Mullainadhan, P., 1997. Activation of prophenoloxidase in the plasma and haemocytes of the marine mussel Perna viridis Linnaeus. Dev. Comp. Immunol. 21 (1):1-12. http://dx.doi.org/10.1016/S0145$\underline{305 X(97) 00004-9 .}$.

Bado-Nilles, A., Gagnaire, B., Thomas-Guyon, H., Le Floch, S., Renault, T., 2008. Effects of 16 pure hydrocarbons and two oils on haemocyte and haemolymphatic parameters in the Pacific oyster, Crassostrea gigas (Thunberg). Toxicol. in Vitro 22 (6):1610-1617. http://dx.doi.org/10.1016/j.tiv.2008.04.011.

Bado-Nilles, A., Quentel, C., Auffret, M., Le Floch, S., Gagnaire, B., Renault, T., Thomas-Guyon, H., 2009. Immune effects of HFO on European sea bass, Dicentrarchus labrax, and Pacific oyster, Crassostrea gigas. Ecotoxicol. Environ. Saf. 72:1446-1454. http://dx.doi.org/10.1016/j.ecoenv.2009.04.001.

Baussant, T., Sanni, S., Skadsheim, A., Jonsson, G., Børseth, J.F., Gaudebert, B., 2001. Bioaccumulation of polycyclic aromatic compounds: 2. Modeling bioaccumulation in marine

organisms chronically exposed to dispersed oil. Environ. Toxicol. Chem. 20: 1185-1195. http://dx.doi.org/10.1002/etc.5620200607.

Baussant, T., Ortiz-Zarragoitia, M., Cajaraville, M.P., Bechmann, R.K., Taban, I.C., Sanni, S., 2011. Effects of chronic exposure to dispersed oil on selected reproductive processes in adult blue mussels (Mytilus edulis) and the consequences for the early life stages of their larvae. Mar. Pollut. Bull. 62:1437-1445. http://dx.doi.org/10.1016/j.marpolbul.2011.04.029. 
Beliaeff, B., Burgeot, T., 2002. Integrated biomarker response: a useful tool for ecological risk assessment. Environ. Toxicol. Chem. 21:1316-1322. http://dx.doi.org/10.1002/etc.5620210629.

Beliaeff, B., O'Connor, T.P., Claisse, D., 1998. Comparison of chemical concentrations in mussels and oysters from the United States and France. Environ. Monit. Assess. 49: 87-95. http://dx.doi.org/10.1023/A:1005766321323.

Beyer, J., Trannum, H.C., Bakke, T., Hodson, P.V., Collier, T.K., 2016. Environmental effects of the Deepwater Horizon oil spill: a review. Mar. Pollut. Bull. 110 (1):28-51. http://dx.doi.org/10.1016/j.marpolbul.2016.06.027.

Bolt, H.M., 2014. Fighting oil spills at sea and toxicology of complex mixtures. Arch. Toxicol. 88:541-542. http://dx.doi.org/10.1007/s00204-014-1202-1.

Broeg, K., Lehtonen, K.K., 2006. Indices for the assessment of environmental pollution of the Baltic Sea coasts: integrated assessment of a multi-biomarker approach. Mar. Pollut. Bull. 53:508-522. http://dx.doi.org/10.1016/j.marpolbul.2006.02.004.

Brooks, S., Harman, C., Zaldibar, B., Izagirre, U., Glette, T., Marigómez, I., 2011. Integrated biomarker assessment of the effects exerted by treated produced water from an onshore natural gas processing plant in the North Sea on the mussel Mytilus edulis. Mar. Pollut. Bull. 62:327-339. http://dx.doi.org/10.1016/j.marpolbul.2010.10.007.

Cajaraville, M.P., Bebianno, M.J., Blasco, J., Porte, C., Sarasquete, C., Viarengo, A., 2000. The use of biomarkers to assess the impact of pollution in coastal environments of the Iberian peninsula: a practical approach. Sci. Total Environ. 247:295-311. http://dx.doi.org/10.1016/S0048-9697(99)00499-4.

Culling, C.F.A., 1974. Handbook of Histopathological and Histochemical techniques. Third ed. ButterworthHeinemann, London. Díez, G., 1996. Correlación multiespecífica entre biomarcadores celulares y tisulares de estrés ambiental y niveles biodisponibles de polucionantes orgánicos y metálicos un estudio de campo. PhD thesis. University of the Basque Country.

Dodor, D.E., Hwang, H.-M., Ekunwe, S.I.N., 2004. Oxidation of anthracene and benzo [a]pyrene by immobilized laccase from Trametes versicolor. Enzym. Microb. Technol. 35:210-217. http://dx.doi.org/10.1016/j.enzmictec.2004.04.007.

Duquesne, S., Liess, M., Bird, D.J., 2004. Sub-lethal effects of metal exposure: physiological and behavioural responses of the estuarine bivalve Macoma balthica. Mar. Environ. Res. 58 (2-5):245-250. http://dx.doi.org/10.1016/j.marenvres.2004.03.066.

FAO (Food and Agriculture Organization), 2014. The state of world fisheries and aquaculture 2014 (Rome). 
Frantzen, M., Regoli, F., Ambrose,W.G., Nahrgang, J., Geraudie, P., Benedetti, M., Camus, L., 2016. Biological effects of mechanically and chemically dispersed oil on the Icelandic scallop (Chlamys islandica). Ecotoxicol. Environ. Saf. 127:95-107. http://dx.doi.org/10.1016/j.ecoenv.2016.01.011.

Fusey, P., Oudot, J., 1976. Comparaison de deux méthodes d'évaluation de la biodégradation des hydrocarbures in vitro. Mater. Org. 4, 241-251.

Gagnaire, B., Thomas-Guyon, H., Burgeot, T., Renault, T., 2006. Pollutant effects on Pacific oyster, Crassostrea gigas (Thunberg), hemocytes: screening of 23 molecules using flow cytometry. Cell Biol. Toxicol. 22:1-14. http://dx.doi.org/10.1007/s10565-006-0011-6.

Garmendia, L., Soto, M., Vicario, U., Kim, Y., Cajaraville, M.P., Marigómez, I., 2011. Application of a battery of biomarkers in mussel digestive gland to assess long-term effects of the Prestige oil spill in Galicia and Bay of Biscay: tissue-level biomarkers and histopathology. J. Environ. Monit. 13:915-932. http://dx.doi.org/10.1039/c0em00410c.

Goodbody-Gringley, G., Wetzel, D.L., Gillon, D., Pulster, E., Miller, A., Ritchie, K.B., 2013. Toxicity of Deepwater Horizon source oil and the chemical dispersant, Corexit® 9500, to coral larvae. PLoS One 8, e45574. http://dx.doi.org/10.1371/journal.pone.0045574.

Greer, C.D., Hodson, P.V., Li, Z., King, T., Lee, K., 2012. Toxicity of crude oil chemically dispersed in a wave tank to embryos of Atlantic herring (Clupea harengus). Environ. Toxicol. Chem. 31:1324-1333. http://dx.doi.org/10.1002/etc.1828.

Hannam, M.L., Bamber, S.D., Moody, J.A., Galloway, T.S., Jones, M.B., 2009. Immune function in the Arctic scallop, Chlamys islandica, following dispersed oil exposure. Aquat. Toxicol. 92:187-194. http://dx.doi.org/10.1016/j.aquatox.2009.01.010.

Harrison, F.L., Knezovich, J.P., Rice Jr., D.W., 1984. The toxicity of copper to the adult and early life stages of the freshwater clam, Corbicula manilensis. Arch. Environ. Contam. Toxicol. 13, 85-92.

Hyötylänen, T., Karels, A., Oikari, A., 2002. Assessment of bioavailability and effects of chemicals due to remediation actions with caging mussels (Anodonta Anatina) at a creosote-contaminated lake sediment site. Water Res. 36:44974504. http://dx.doi.org/10.1016/S0043-1354(02)00156-2.

Izagirre, U., Marigómez, I., 2009. Lysosomal enlargement and lysosomal membrane destabilisation in mussel digestive cells measured by an integrative index. Environ. Pollut. 157:1544-1553. http://dx.doi.org/10.1016/j.envpol.2009.01.011.

Kim, Y., Ashton-Alcox, K.A., Powell, E.N., 2006. Histological techniques for marine bivalve molluscs: Update (NOAA technical memorandum NOS NCCOS 27). NOAA/National Centers for Coastal Ocean Science, Silver Spring, MD. 
Krishnakumar, P.K., Casillas, E., Varanasi, U., 1997. Cytochemical responses in the digestive tissue of Mytilus edulis Complex exposed to microencapsulated PAHs or PCBs. Comp. Biochem. Physiol. Part C Pharmacol. Toxicol. Endocrinol. 118:11-18. http://dx.doi.org/10.1016/S0742-8413(97)00076-5.

Lee, K., Boufadel, M., Chen, B., Foght, J., Hodson, P., Swanson, S., Venosa, A., 2015. Expert panel report on the behaviour and environmental impacts of crude oil released into aqueous environments. R. Soc, Canada, Ottawa.

Lekube, X., Izagirre, U., Soto, M., Marigómez, I., 2014. Lysosomal and tissue-level biomarkers in mussels crosstransplanted among four estuaries with different pollution levels. Sci. Total Environ. 472, 36-48.

Lobel, P.B., Wright, D.A., 1982. Relationship between body zinc concentration and allometric growth measurements in themussel Mytilus edulis.Mar. Biol. 66:145-150. http://dx.doi.org/10.1007/BF00397187.

Lowe, D.M., Moore, M.N., Clarke, K.R., 1981. Effects of oil on digestive cells in mussels: quantitative alterations in cellular and lysosomal structure. Aquat. Toxicol. 1: 213-226. http://dx.doi.org/10.1016/0166-445X(81)90016-3.

Luna-Acosta, A., Rosenfeld, E., Amari, M., Fruitier-Arnaudin, I., Bustamante, P., Thomas-Guyon, H., 2010. First evidence of laccase activity in the Pacific oyster Crassostrea gigas. Fish Shellfish Immunol. 28:719-726. http://dx.doi.org/10.1016/j.fsi.2010.01.008.

Luna-Acosta, A., Kanan, R., Le Floch, S., Huet, V., Pineau, P., Bustamante, P., Thomas-Guyon, H., 2011. Enhanced immunological and detoxification responses in Pacific oysters, Crassostrea gigas, exposed to chemically dispersed oil. Water Res. 45:4103-4118. http://dx.doi.org/10.1016/j.watres.2011.05.011.

Luna-Acosta, A., Bustamante, P., Budzinski, H., Huet, V., Thomas-Guyon, H., 2015. Persistent organic pollutants in a marine bivalve on the Marennes-Oléron Bay and the Gironde estuary (French Atlantic Coast)-Part 2: potential biological effects. Sci. Total Environ. 514:511-522. http://dx.doi.org/10.1016/j.scitotenv.2014.10.050.

Lunel, T., 1995. The Braer spill: Oil fate governed by dispersion. International oil spill conference. American Petroleum Institute, pp. 955-956.

Marigómez, I., Baybay-Villacorta, L., 2003. Pollutant-specific and general lysosomal responses in digestive cells of mussels exposed to model organic chemicals. Aquat. Toxicol. 64:235-257. http://dx.doi.org/10.1016/S0166445X(03)00056-0.

Marigomez, I., Soto, M., Cancio, I., Orbea, A., Garmendia, L., Cajaraville, M.P., 2006. Cell and tissue biomarkers in mussel, and histopathology in hake and anchovy from Bay of Biscay after the Prestige oil spill (monitoring campaign 2003). Mar. Pollut. Bull. 53: 287-304. http://dx.doi.org/10.1016/j.marpolbul.2005.09.026. 
Marigómez, I., Garmendia, L., Soto, M., Orbea, A., Izagirre, U., Cajaraville, M.P., 2013a. Marine ecosystem health status assessment through integrative biomarker indices: a comparative study after the Prestige oil spill "mussel watch.”. Ecotoxicology 22: 486-505. http://dx.doi.org/10.1007/s10646-013-1042-4.

Marigómez, I., Zorita, I., Izagirre, U., Ortiz-Zarragoitia, M., Navarro, P., Etxebarria, N., Orbea, A., Soto, M., Cajaraville,M.P., 2013b. Combined use of native and caged mussels to assess biological effects of pollution through the integrative biomarker approach. Aquat. Toxicol. 136:32-48. http://dx.doi.org/10.1016/j.aquatox.2013.03.008.

Mauduit, F., Domenici, P., Farrell, A.P., Lacroix, C., Le Floch, S., Lemaire, P., et al., 2016. Assessing chronic fish health: an application to a case of an acute exposure to chemically treated crude oil. Aquat. Toxicol. 178:197-208. http://dx.doi.org/10.1016/j.aquatox.2016.07.019.

Milinkovitch, T., Ndiaye, A., Sanchez, W., Le Floch, S., Thomas-Guyon, H., 2011. Liver antioxidant and plasma immune responses in juvenile golden grey mullet (Liza aurata) exposed to dispersed crude oil. Aquat. Toxicol. 101:155-164. http://dx.doi.org/10.1016/j.aquatox.2010.09.013.

Moore, M.N., Icarus Allen, J., McVeigh, A., 2006. Environmental prognostics: an integrated model supporting lysosomal stress responses as predictive biomarkers of animal health status. Mar. Environ. Res. 61:278-304. http://dx.doi.org/10.1016/j.marenvres.2005.10.005.

Mu, J., Jin, F., Ma, X., Lin, Z.,Wang, J., 2014. Comparative effects of biological and chemical dispersants on the bioavailability and toxicity of crude oil to early life stages of marine medaka (Oryzias melastigma). Environ. Toxicol. Chem. 33:2576-2583. http://dx.doi.org/10.1002/etc.2721.

Neumann, N., Stafford, J., Barreda, D., Ainsworth, A., Belosevic, M., 2001. Antimicrobial mechanisms of fish phagocytes and their role in host defense. Dev. Comp. Immunol. 77:339-347. http://dx.doi.org/10.1016/S0145$\underline{305 X(01) 00037-4}$.

NRC (National Research Council), 2005. Oil spill dispersants: Efficacy and effects. The National Academies Press, Washington, DC http://dx.doi.org/10.17226/11283.

O’Connor, T.P., 2002. National distribution of chemical concentrations in mussels and oysters in the USA. Mar. Environ. Res. 53 (2):117-143. http://dx.doi.org/10.1016/S0141-1136(01)00116-7.

Orbea, A., Ortiz-Zarragoitia, M., Solé, M., Porte, C., Cajaraville, M.P., 2002. Antioxidant enzymes and peroxisome proliferation in relation to contaminant body burdens of PAHs and PCBs in bivalve molluscs, crabs and fish from the Urdaibai and Plentzia estuaries (Bay of Biscay). Aquat. Toxicol. 58, 75-98.

Ostroumov, S.A., 2003. Studying effects of some surfactants and detergents on filter-feeding bivalves. In: Martens, K. (Ed.), Aquatic biodiversity, developments in hydrobiology. Springer, Netherlands, Houten :pp. 341-344. http://dx.doi.org/10.1007/978-94-007-1084-9_24. 
Rand, G.M., Petrocelli, S.R., 1985. Fundamentals of aquatic toxicology: Methods and applications. Hemisphere Publishing Corporation, Washington.

Sammarco, P.W., Kolian, S.R., Warby, R.A.F., Bouldin, J.L., Subra, W.A., Porter, S.A., 2013. Distribution and concentrations of petroleum hydrocarbons associated with the BP/deepwater Horizon oil spill, Gulf of Mexico. Mar. Pollut. Bull. 73:129-143. http://dx.doi.org/10.1016/j.marpolbul.2013.05.029.

Shaw, J.P., Dondero, F., Moore, M.N., Negri, A., Dagnino, A., Readman, J.W., Lowe, D.R., Frickers, P.E., Beesley, A., Thain, J.E., 2011. Integration of biochemical, histochemical and toxicogenomic indices for the assessment of health status of mussels from the Tamar estuary, UK. Mar. Environ. Res. 72:13-24. http://dx.doi.org/10.1016/j.marenvres.2011.05.003.

Smith, P.K., Krohn, R.I., Hermanson, G.T., Mallia, A.K., Gartner, F.H., Provenzano, M.D., Fujimoto, E.K., Goeke, N.M., Olson, B.J., Klenk, D.C., 1985. Measurement of protein using bicinchoninic acid. Anal. Biochem. 150:76-85. http://dx.doi.org/10.1016/0003-2697(85)90442-7.

Stebbing, A.R.D., 1998. A theory for growth hormesis. Mutat. Res. Fundam. Mol. Mech. Mutagen. 403 (1):249-258. http://dx.doi.org/10.1016/S0027-5107(98)00014-1.

Therond, P., Gerbaud, P., Dimon, S., Anderson,W.B., Evain-Brion, D., Raynaud, F., 1996. Antioxidant enzymes in psoriatic fibroblasts and erythrocytes. J. Investig. Dermatol. 106: 1325-1331. http://dx.doi.org/10.1111/15231747.ep12349055.

Valavanidis, A., Vlahogianni, T., Dassenakis, M., Scoullos, M., 2006. Molecular biomarkers of oxidative stress in aquatic organisms in relation to toxic environmental pollutants. Ecotoxicol. Environ. Saf. 64 (2):178-189. http://dx.doi.org/10.1016/j.ecoenv.2005.03.013.

Van Scoy, A.R., Yu Lin, C., Anderson, B.S., Philips, B.M., Martin, M.J., McCall, J., Todd, C.R., Crane, D., Sowby, M.L., Viant, M.R., Tjeerdema, R.S., 2010. Metabolic responses produced by crude versus dispersed oil in Chinook salmon pre-smolts via NMR-based metabolomics. Ecotoxicol. Environ. Saf. 73, 710-717.

Vega, M.M., Marigomez, J.A., Angulo, E., 1989. Quantitative alterations in the structure of the digestive cell of Littorina littorea on exposure to cadmium. Mar. Biol. 103: 547-553. http://dx.doi.org/10.1016/j.cbi.2007.01.018.

Verlecar, X.N., Jena, K.B., Chainy, G.B.N., 2007. Biochemical markers of oxidative stress in Perna viridis exposed to mercury and temperature. Chem. Biol. Interact 167 (3): 219-226. http://dx.doi.org/10.1016/j.cbi.2007.01.018.

Viarengo, A., Canesi, L., Pertica, M., Poli, G., Moore, M.N., Orunesu, M., 1990. Heavy metal effects on lipid peroxidation in the tissues of Mytilus galloprovincialis. Comp. Biochem. Physiol. Part C Comp. Pharmacol. 97:3742. http://dx.doi.org/10.1016/0742-8413(90)90168-9. 
Vignier, J., Donaghy, L., Soudant, P., Chu, F.L.E., Morris, J.M., Carney, M., et al., 2015. Impacts of Deepwater Horizon oil and associated dispersant on early development of the eastern oyster Crassostrea virginica. Mar. Pollut. Bull. 100 (1):426-437. http://dx.doi.org/10.1016/j.marpolbul.2015.08.011.

Webby, A., Ling, N., 2016. Acute sublethal toxicity of MV Rena contaminants (heavy fuel oil, oil dispersant and cryolite) to finfish and rock lobster. N.Z. J. Mar. Fresh. Res. 50 (1):144-158. http://dx.doi.org/10.1080/00288330.2015.110436.

Weibel, E.R., 1979. Point counting methods. Stereol. methods 1, 101-161.

Widdows, J., Phelps, D.K., Galloway,W., 1981. Measurement of physiological condition of mussels transplanted along a pollution gradient in Narragansett Bay. Mar. Environ. Res. 4 (3):181-194. http://dx.doi.org/10.1016/01411136(81)90033-7.

Winston, G.W., 1991. Oxidants and antioxidants in aquatic animals. Comp. Biochem. Physiol. Part C Comp. Pharmacol. 100:173-176. http://dx.doi.org/10.1016/0742-8413(91)90148-M.

Wu, D., Wang, Z., Hollebone, B., McIntosh, S., King, T., Hodson, P.V., 2012. Comparative toxicity of four chemically dispersed and undispersed crude oils to rainbow trout embryos. Environ. Toxicol. Chem. 31:754-765. http://dx.doi.org/10.1002/etc.1739.

Zar, J.H., 2010. Biostatistical analysis. fifth ed. Prentice Hall, New Jersey.

Zorita, I., Ortiz-Zarragoitia, M., Soto, M., Cajaraville, M.P., 2006. Biomarkers in mussels from a copper site gradient (Visnes, Norway): an integrated biochemical, histochemical and histological study. Aquat. Toxicol. 78, S109-S116. 


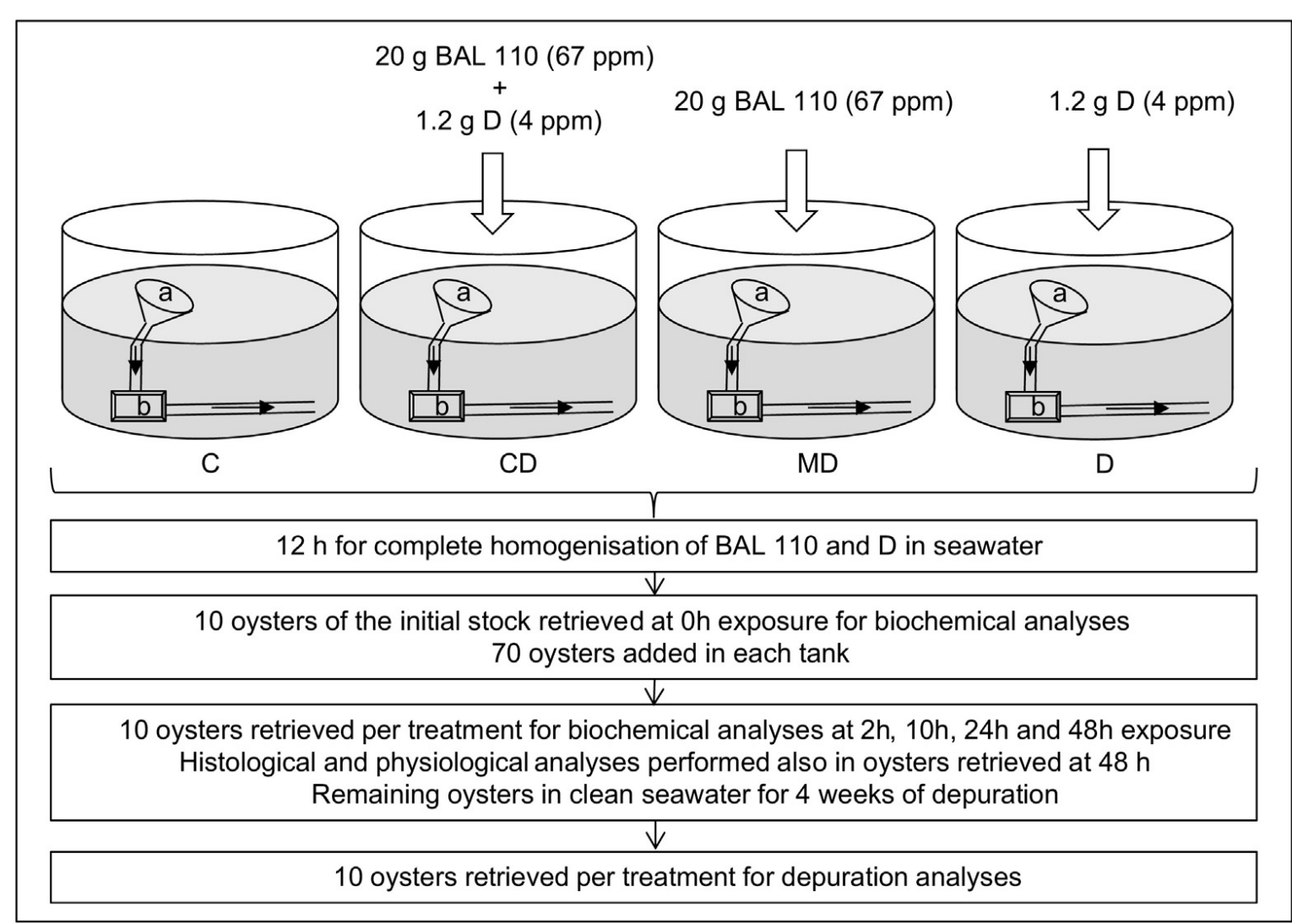

Figure 1. The following treatments were carried out: C: control, with non-contaminated seawater; CD: chemical dispersion, made by pouring $20 \mathrm{~g}$ of BAL 110 (67 ppm) and $1.2 \mathrm{~g}$ of chemical dispersant (4 ppm) into the funnel of the homogenization system; MD: mechanical dispersion, made by pouring $20 \mathrm{~g}$ of BAL $110(67 \mathrm{ppm})$ into the funnel; D: chemical dispersant (D), by pouring $1.2 \mathrm{~g}$ of chemical dispersant into the funnel. The homogenization system constituted of a funnel (a) linked to a water pump (b) in a 3001 seawater tank. $\rightarrow$ : Direction of seawater and/or contaminant movement through the experimental system. In a first step, chemicals were poured into the tanks. Once chemicals were completely homogenized in the tanks, oysters were introduced into the tanks for $48 \mathrm{~h}$. Further on, oysters were depurated in non-contaminated seawater for 4 wk. Three replicates of the whole experimental set upwere carried out in parallel $(\times 3)$. 


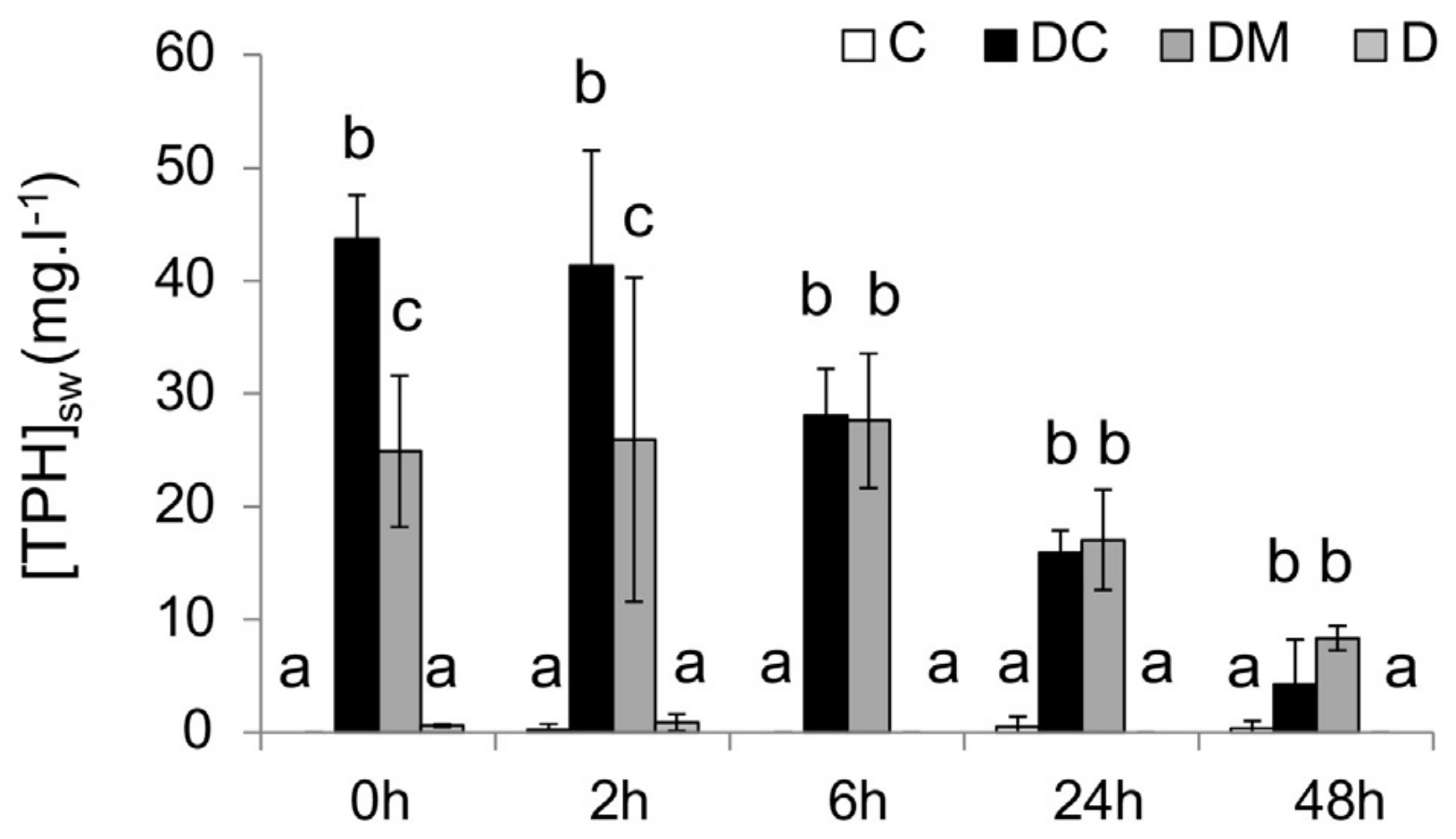

Figure 2. Total petroleum hydrocarbon concentration in seawater $\left([\mathrm{TPH}]_{\mathrm{sw}}\right)$ during the $48 \mathrm{~h}$ exposure period. Mean \pm standard error $(\mathrm{N}=9)$. C: control; $\mathrm{CD}$ : chemical dispersion; $\mathrm{MD}$ : mechanical dispersion; D: dispersant. Superscript letters indicate significant $(\mathrm{p}<0.05)$ differences between treatments at each experimental time. 


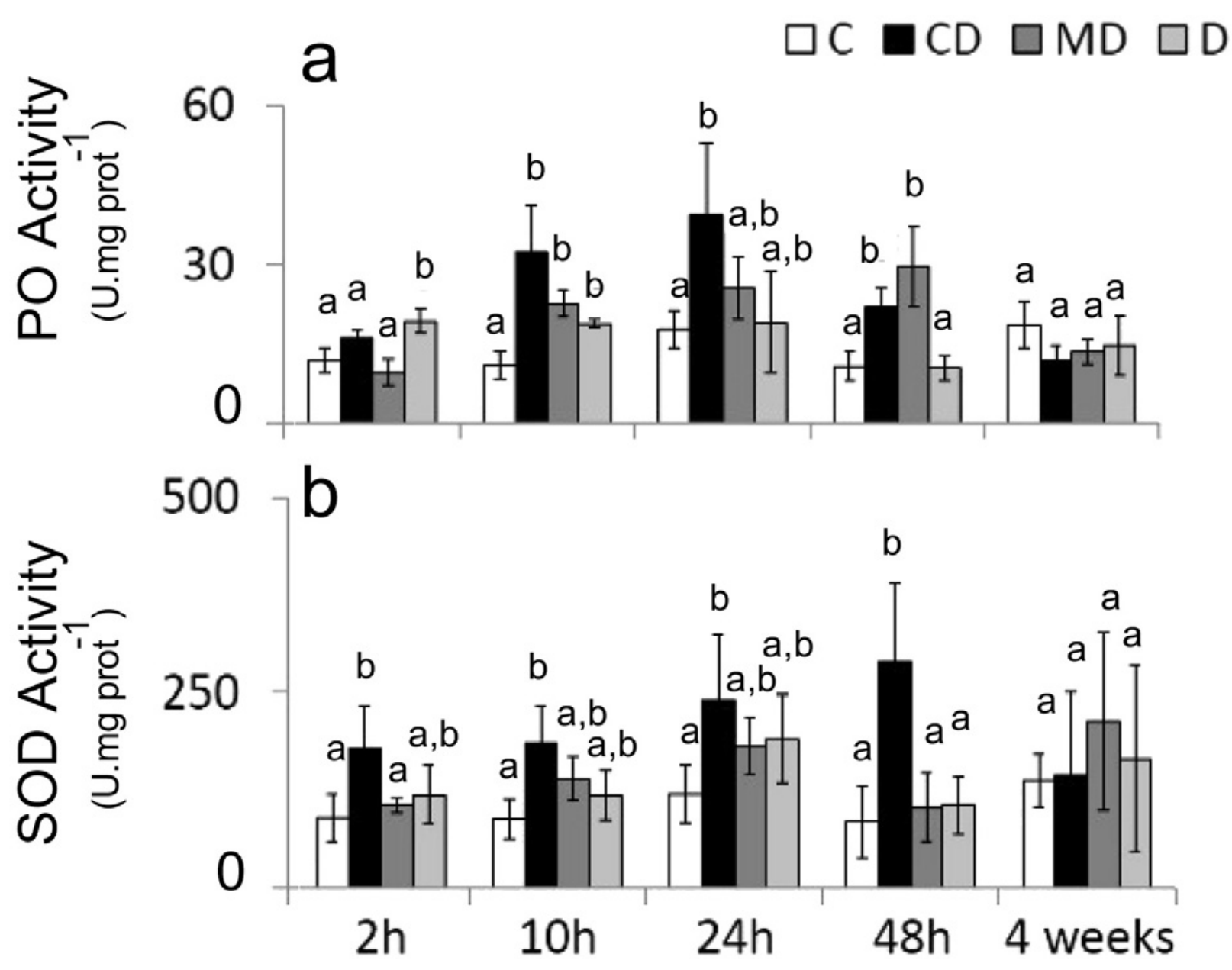

Figure 3. Biomarkers (mean \pm standard error; $\mathrm{N}=9$ ) determined in plasma of $C$. gigas on exposure at different exposure times to chemically (CD) and mechanically dispersed oil (MD) and to dispersant (D), as well as non exposed control oysters (C). a. Laccase-type phenoloxidase (PO) activity; b. Superoxide dismutase (SOD) activity. Superscript letters indicate significant $(\mathrm{p}<0.05)$ differences between treatments at each experimental time. 


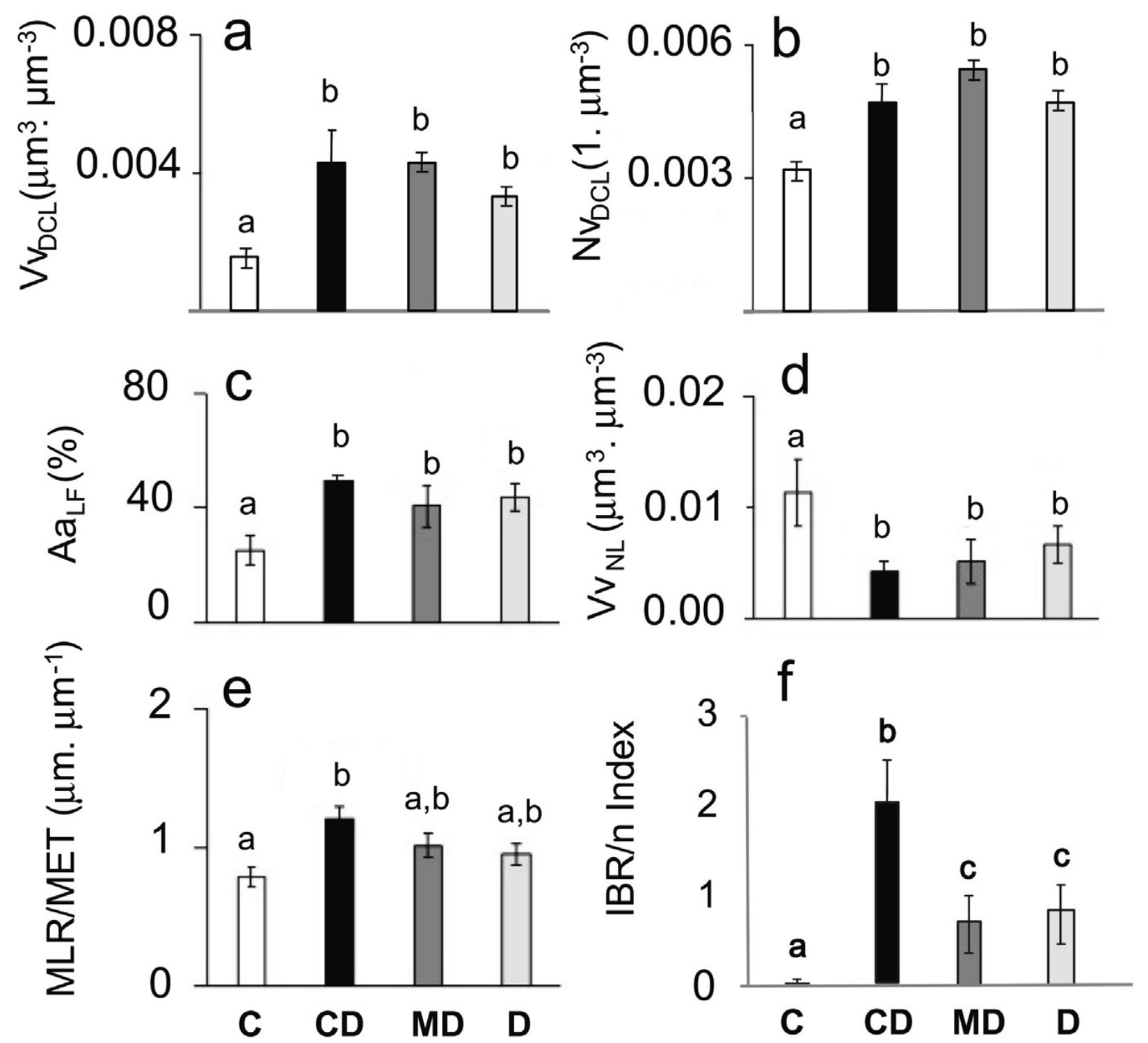

Figure 4. (a-e) Biomarkers (mean \pm standard error; $\mathrm{N}=30$ ) determined in the digestive gland of $C$. gigas on exposure for $48 \mathrm{~h}$ to chemically (CD) and mechanically dispersed oil (MD) and to dispersant (D), as well as non exposed control oysters (C): (a) Lysosomal volume density (VvDCL); (b) Lysosomal numerical density $\left(\mathrm{NV}_{\mathrm{DCL}}\right)$; (c) Volume density of intracellular neutral lipids $\left(\mathrm{V}_{\mathrm{NL}}\right)$; (d) Relative section area of lipofuscins in relation the section area of the digestive cells (AaLF); and (e) Mean luminal radius mean epithelium thickness radius (MLR/MET). (f) IBR/n index (mean \pm standard error; $\mathrm{N}=12 ; 4$ experimental groups $\times 3$ replicates). Superscript letters indicate significant $(\mathrm{p}<0.05)$ differences between treatments at each experimental time. 

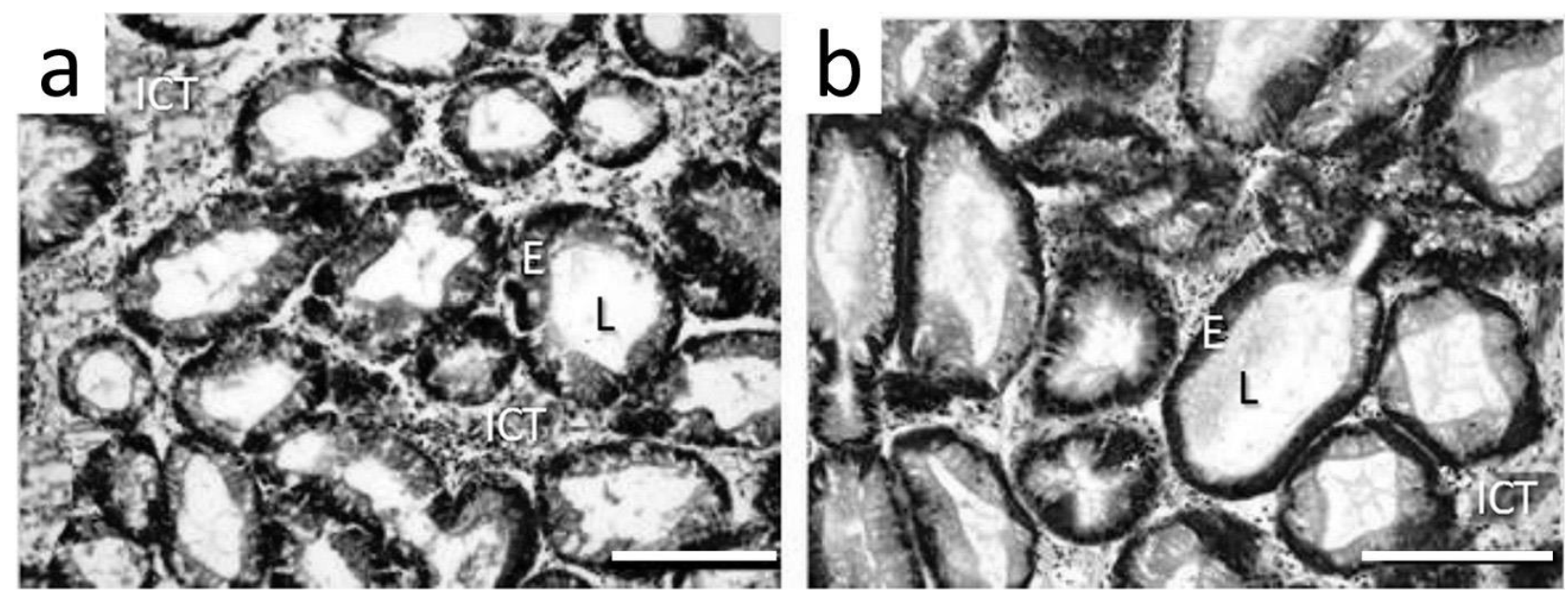

Figure 5. Histological sections $(5 \mu \mathrm{m} ; \mathrm{H} / \mathrm{E})$ of the digestive gland of $C$. gigas: (a) control; (b) $\mathrm{CD}$ treatment. Note the swelling of the lumen and the epithelial thinning in the CD treated oyster in comparison with the control one. Scale bar: $100 \mu \mathrm{m}$; ICT: interstitial connective tissue; E: epithelium; L: lumen. 
